\title{
A Study on Continued usage Factors of Technology Based Banking Services in Commercial Banks
}

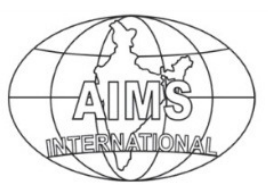

Volume 13, Number 1

January 2019, pp. 53-67

\author{
Chandana Goswami \\ Kamaleswar Boro \\ Tezpur University \\ (cg1@ @ezu.ernet.in) \\ (brokennth@gmail.com)
}

The study is an attempt to identify factors that influence bank customers to continue technology based banking services usage such as ATM cum Debit Cards, Credit Cards, Internet Banking, Mobile Banking, and M-Pesa. Data was collected from two districts of Assam. A total of 800 samples were collected, out of which 785 were found valid for data analysis. Descriptive statistics as well as inferential statistics such as factor analysis and regression analysis were used in order to analyze the data. The result showed that system characteristics, perceived risk, perceived usefulness and perceived trust significantly predicted continued usage behaviour of technology based banking services usage by bank customers. Significant association was found with respect to continued usage of technology based banking services with respect to demographic variables such as age group, level of education, gender, level of income and occupation of respondents.

Keywords: Internet Banking, Mobile Baking, Technology and Banking, Customer Perception

\section{Introduction}

A sound banking system is a backbone of a nation's economy. Without maintaining a sound financial system, it is difficult for a country to experience economic progress. The market across banking system in India includes 27 public sector undertaking banks, 45 foreign banks (Reserve Bank of India, 2018), 26 private banks, 56 RRB's (Regional Rural Banks), 93,913 Rural Cooperative Banks and 1,574 Urban Cooperative Banks (India brand Equity Foundation, 2018). More than 70 percent of assets are controlled by public-sector banks, leaving relatively lesser share of assets for private banks (Reserve Bank of India, 2018). According to RBI, Automated Teller Machine refers to a computerized machine which provides facilities like account access, cash dispense and deposit, mini or short statements, bill payment, a cheque book request and purchase of mobile reload vouchers (Reserve Bank of India, 2016). Internet banking, also referred to as online banking, virtual banking or e-banking, is an electronic payment system enabling bank customers to perform a series of financial transactions by using the banks website (Cashlessindia.gov.in, n.d.). Through these technology based banking mediums bank customers can perform a range of financial transactions such as National Electronic Funds Transfer, Real Time Gross Settlement and Immediate Payment Service. National Electronic Funds Transfer or NEFT in short refers to an online financial 
transaction or payment system which facilitates one-to-one money transfer. Through this online payment system, individuals, corporate houses and firms can transfer funds electronically to the account of any other individual, corporate or firm from any bank branches within the country of jurisdiction covered in the scheme. Through NEFT facility, walk in customers or individuals not having a bank account can also deposit cash with the directions of funds transfer across branches enabled with NEFT facility (Cashlessindia.gov.in, n.d). NEFT scheme operates in batches on an hourly basis and currently includes twelve settlements on weekdays from 8 am to $7 \mathrm{pm}$ all throughout Monday to Friday and there are six settlements on Saturdays from 8 am to $1 \mathrm{pm}$ (Cashlessindia.gov.in, n.d.). RTGS or Real Time Gross Settlement facilitates real time continuous settlement process of funds transfers. 'Real Time' indicates processing instructions during the period the instructions are received instead of some other time later. 'Gross Settlement' indicates funds settlement instructions occurring individually. RTGS funds settlements are irrevocable and final as these take place within the books of Reserve Bank of India (Cashlessindia.gov.in, n.d). This facility is primarily designed for large volume money transactions and the threshold amount is Rs. 2 lakh with no upper ceiling. The RTGS facility is available for bank customer from 9.00 to 16.30 hours across week days and on Saturdays the same transaction facility is available from 9.00 to 14:00 hours. IMPS or Immediate Payment Service facilitates instant, $24 \times 7$, electronic interbank fund transfer using mobile phones. It is considered as an emphatic tool for transferring instant cash within banks through mobile, ATM and internet. IMPS are safe for use and are also considered as economical financial transaction (Cashlessindia.gov.in, n.d). This study has made an attempt to identify factors, which influence bank customers to continue using technology based banking services such as ATM, debit cards, mobile and internet banking, National Electronic Funds Transfer, Immediate Payment Service and Real Time Gross Settlement facilities.

\section{Literature Review}

The recommendation of the Narasimham Committee in 1991 was the game changer in the Indian banking industry. Along with other recommendations, the committee recommended free entry of private and foreign banks and bringing of new technologies to render services for customers. Under such situation the public sector banks which had a strong dominance, faced steep competition with private banks. This resulted in a number of product innovations as both private as well as public sector banks embraced technology as their new medium to serve the customers. With these product innovations, banks attempted to increase their speed and accuracy as well as reduce their transaction cost. By then, service orientation among banks was already transformed to anywhere, anytime, anyhow and any type of banking from the traditional brick and mortar face to face physical banking. However, in this new millennium along with technological intervention marking a paradigm shift in banking industry, all challenges have not been met.

For instance, Raghavan (2006) points out that banks are still relying on surveys that may have been specifically done for consumers who might no longer be existent today. Therefore, he suggested focusing on behavioral analysis approach for fine tuning their products. He further stated that banks may be very selective while choosing their customers. 
In terms of technology based service acceptance by users, Fred Davis' contribution to the literature cannot be ignored as most research seems to heavily rely on his studies. Davis through his "Technology Acceptance Model," defined that users intention to use technology can be determined through their attitude, which in turn is dependent on perceived ease of use and perceived usefulness (Davis, 1989). According to Davis, if user's attitude of perceived usefulness and perceived ease of use is high then new technology is easily accepted (Davis, 1989). But even though these two determinant variables are high in technology based services like e-banking, users are still reluctant to adopt e-banking services (Dubey and Desmukh, 2013). This opened up new avenues for research in order to study or identify other distinguishing variables that influence technology based service usage.

According to Lim et al, (2005), perceived ease of use and perceived usefulness are two factors that act as strong determinants of technology acceptance by users and have been confirmed by many researchers through different studies. Apart from these two factors, Lim et al, (2005) tested two other variables namely "perceived enjoyment and perceived security" to have positive impact on technology usage behavior.

Haque et al, (2009), studied customer adoption of electronic banking in Malaysia and found security of transaction to be the most significant factor in expanding ebanking services of Malaysia. The study confirmed that trust and security of consumers can increase confidence of e-banking users in Malaysia.

Farzianpour et al., (2014) tested all types of risk factors like: social risk, performance risk, security risk, time loss risk, privacy risk and innovations adoption risk towards customer's adoption of online banking services in Iran. The results showed that all types of risk except social risk significantly impact user's adoption of internet banking.

Sohail \& Shanmugham (2012) studied customer's preference of electronic banking and factors that may influence the adoption of users among Malaysian customers. In their study they made a comparison between "technology based banking users" and "conventional banking users" based on different demographics such as monthly income, age and education level of respondents. The result showed that demographic characteristic "monthly income" was found significant among technology based banking users and conventional banking users. Other demographic variables like "age" and "level of education" was found insignificant. Hence, they concluded that the tendency for adopting technology based service among older and younger people is the same and literacy rate has nothing to do with consumer adoption of technology based banking services.

Studies undertaken by Joshua \& Koshy (2011) in Karnataka region of India reveal contradicting results when compared to studies of Sohail \& Shanmugham (2012). In their study Joshua \& Koshy (2011) found that internet banking usage trend tend to vary with various demographic characteristics like gender, age and income. Through their analysis, the adoption level of technology based banking channels were found to be more among younger population (below 36 years of age), higher income individuals (Rs. (3-4) lakhs and above per annum) and respondents with higher qualifications (above graduate). Among technology based service delivery channels ATM users were found to be the highest, followed by internet banking users, telebanking users stood third followed by mobile banking users. 
Lewis (1991) revealed issues related to using of ATM services by users. According to his study, operational problems, lack of privacy and personal safety were some negative factors regarding ATM usage.

Chandrasekar (2012) in his study undertaken in Bangalore region of India classified encouraging and discouraging factors to analyze variables and factors influencing internet banking adoption. Factors that he identified as encouraging factors include 'ease of use' and 'operational advantage' and factors that he found discouraging among customers were 'perceived risk, personal limitations, and infrastructure constraints'. Infrastructure constraints such as quality of internet connection, disruption during online transaction leads to user's dissatisfaction and discourages them from using technology based services.

A comparative study of internet penetration by Chen \& Wellman (2004) in eight countries viz: UK, US, Germany, Italy, Japan, Korea, China, and Mexico, found that gender, life stage, socio economic status and geographical location affect individuals technology based service usage significantly. The research found that socio economic status of internet users in developing and developed countries were educated and well off than non internet users. Male individuals were more likely to use internet than female. Internet penetration was found to be more significant among younger people than older ones. Geographical region wise more affluent nations were seen switching to internet usage as compared to developing and poor countries.

Variables from Literature Review
\begin{tabular}{|l|l|}
\hline \multicolumn{1}{|c|}{ Variables } & \multicolumn{1}{|c|}{ Studies } \\
\hline Perceived ease of use and Perceived usefulness & (Davis, 1989); Lim et al, (2005) \\
\hline Perceived enjoyment and Perceived security & Lim et al, (2005) \\
\hline Trust and Security & $\begin{array}{l}\text { Haque, Tarofder, Rahman, and } \\
\text { Raquib (2009) }\end{array}$ \\
\hline $\begin{array}{l}\text { Risk factors: social risk, performance risk, } \\
\text { security risk, time loss risk, privacy risk and } \\
\text { innovations adoption risk }\end{array}$ & $\begin{array}{l}\text { Farzianpour, Pishdar, Shakib and } \\
\text { Toloun (2014) }\end{array}$ \\
\hline $\begin{array}{l}\text { Demographic variables: monthly income, age, } \\
\text { level of education, gender, economic status and } \\
\text { geographical location }\end{array}$ & $\begin{array}{l}\text { Sohail and Shanmugham (2012); } \\
\text { Joshua and Koshy (2011); Chen } \\
\text { \& Wellman (2004) }\end{array}$ \\
\hline $\begin{array}{l}\text { Operational problems, lack of privacy and } \\
\text { personal safety }\end{array}$ & Lewis (1991) \\
\hline $\begin{array}{l}\text { Ease of use and operational advantage, perceived } \\
\text { risk, personal limitations( quality of internet } \\
\text { connection, disruption during online transaction) }\end{array}$ & Chandrasekar (2012) \\
\hline
\end{tabular}

\section{Objective of Study}

The objectives of this study is to identify factors that can influence bank customers to continue usage of technology based banking services such as ATM, Debit Cards, Credit Cards, Internet Banking, Mobile Banking, Immediate Payment System (IMPS), Real Time Gross Settlement Services (RTGS), Mobile-Pesa. In addition, this study also focus towards knowing the impact of demographic variables such as age, gender, income, level of education and occupation with respect to continued 
usage behavior of technology based banking services among bank customers across Assam, India.

\section{Methodology}

Research population for this study includes bank customers using technology based banking services like internet and mobile banking, ATM/Rupay Cards, debit and credit cards. Based on convenience sampling method, a sample of 800 bank customers was surveyed with the help of well developed questionnaire. Out of 800 bank customers surveyed, 785 samples were found valid for data analysis. The survey was administered in Assam, India. Two districts were supposedly selected on the basis of purposive judgment sampling. These two districts were Kamrup Metro and Nagaon. The basis of selection was made considering the inclusiveness of rural and urban customers. Kamrup Metro district comprise of maximum (83 percent) urban population and Nagaon district had the maximum number ( 87 percent) of rural customers (Census of India, 2011).

\section{Data Analysis}

Data was analysed with the help of SPSS 20. Various test statistics like factor analysis, linear regression, one way-ANOVA, frequency and percentage were used to analyze the data. The results obtained are interpreted and outlined in the next section. A total of 42 statements were included in the questionnaire. In order to reduce these statements into smaller number, statistical test factor analysis was conducted. Through factor analysis as urged by Hair et al (2006), it is possible to determine the underlying dimensions within variables. Similar studies like (Capece \& Campisi, 2013; Jolly, 2008; Singh, 2014) have used factor analysis as a statistical test for analysis in determining the overall dimension of variables for technology banking adoption by customers. In order to achieve interpretable results, and a total variance explained of not less than 60 percent, six statements were dropped from the questionnaire, making the number of factors to 36 for final factor analysis. To predict factors that best influence or determine continued usage of technology based banking services by customers, the regression scores of new factors extracted through factor analysis were recorded and stepwise regression was conducted. Similar studies like (Wu at al., 2010; Yoon \& Occena, 2014) have used regression as a statistical tool to identify factors that influence adoption behaviours of technology based banking services. One way-ANOVA was undertaken to identify the significant factor among demographic variables influencing continued usage behaviour of technology based banking service usage among bank customers. Past studies like Jolly (2008); and Singh, (2014) have used one way-ANOVA to test the significance of demographic variables on technology based banking services adoption behavior by customers.

\section{Respondents Profile}

Table 1: Respondents Profile

\begin{tabular}{|c|c|c|c|}
\hline \multicolumn{4}{|c|}{ Gender } \\
\hline & Frequency & Percent & Valid Percent \\
\hline Male & 401 & 51.1 & 51.1 \\
\hline Female & 384 & 48.9 & 48.9 \\
\hline Total & 785 & 100.0 & 100.0 \\
\hline \multicolumn{4}{|c|}{ Age } \\
\hline & Frequency & Percent & Valid Percent \\
\hline
\end{tabular}




\begin{tabular}{|c|c|c|c|}
\hline Less than or equal to 30 & 169 & 21.5 & 21.5 \\
\hline $31-40$ & 249 & 31.7 & 31.7 \\
\hline $41-50$ & 249 & 31.7 & 31.7 \\
\hline 50 Above & 118 & 15.0 & 15.0 \\
\hline Total & 785 & 100.0 & 100.0 \\
\hline \multicolumn{4}{|c|}{ Level of Education } \\
\hline & Frequency & Percent & Valid Percent \\
\hline Primary & 69 & 8.8 & \begin{tabular}{|l|}
8.8 \\
\end{tabular} \\
\hline High School & 93 & 11.8 & 11.8 \\
\hline Secondary & 140 & 17.8 & 17.8 \\
\hline Graduate & 301 & 38.3 & 38.3 \\
\hline Post Graduate & 101 & 12.9 & 12.9 \\
\hline Professional Degree (BE/M.B.B.S/C.A/C.S) & 77 & 9.8 & 9.8 \\
\hline PhD & 4 & .5 & .5 \\
\hline Total & 785 & 100.0 & 100.0 \\
\hline \multicolumn{4}{|c|}{ Occupation } \\
\hline & Frequency & Percent & Valid Percent \\
\hline Student & 102 & 13.0 & 13.0 \\
\hline Service & 205 & 26.1 & 26.1 \\
\hline Self Employed/Professional & 281 & 35.8 & 35.8 \\
\hline Unemployed & 197 & 25.1 & 25.1 \\
\hline Total & 785 & 100.0 & 100.0 \\
\hline \multicolumn{4}{|c|}{ Income (In Rupees) } \\
\hline & Frequency & Percent & Valid Percent \\
\hline less than 20,000 & 427 & 54.4 & 54.4 \\
\hline$(21-40)$ thousand & 254 & 32.4 & 32.4 \\
\hline $41000-60000$ & 59 & 7.5 & 7.5 \\
\hline $61000-80000$ & 18 & 2.3 & 2.3 \\
\hline $81000-100000$ & 17 & 2.2 & 2.2 \\
\hline Above 1 lakhs & 10 & 1.3 & 1.3 \\
\hline Total & 785 & 100.0 & 100.0 \\
\hline
\end{tabular}

\section{Reliability}

According to Maxwell (1992) reliability measures the consistency of results over time and also the accuracy of representation of population considered for the study. Maxwell (1992) states that if the study results can be reproduced through use of a similar methodology, such research instrument used for that study can be considered as reliable. In SPSS, Cronbach's Alpha is the most common measure of internal consistency and reliability. As stated by Hair et al., (1998) reliability scores more than 0.70 is considered as acceptable. The reliability score obtained for this data is .701 as shown in the Table 2 .

Table 2 Reliability Statistics

\begin{tabular}{|c|c|}
\hline Cronbach's Alpha & No of Items \\
\hline 0.701 & 36 \\
\hline
\end{tabular}

Therefore, the items included to measure dimensions of continued usage of technology based banking services for this analysis were reliable. In quantitative 
research, validity refers to whether the research study measures truly what it intends to measure and how truthful results have been achieved (Maxwell, 1992). The appropriateness to conduct factor analysis was measured through two tests namely: Kaiser-Meyer-Olkin Measure of Sampling Adequacy and Bartlett's Test of Sphericity. Kaiser-Meyer-Olkin Measure of Sampling Adequacy ensures that the sample used for carrying out a factor analysis is adequate. Usually Kaiser-MeyerOlkin score above 0.70 is practically considered to be suitable for carrying out a factor analysis. Bartlett's Test of Sphericity measures the variables considered for study are sufficiently correlated and the test must be statistically significant. For this study, Kaiser-Meyer-Olkin Measure of Sampling Adequacy score obtained was .942 (Table 3) which is greater than the threshold requirement for factor analysis and the Bartlett's Test of Sphericity was found to be significant (refer to Table 3) ensuring the appropriateness to conduct factor analysis.

Table 3 KMO and Bartlett's Test

\begin{tabular}{|l|c|c|}
\hline Kaiser-Meyer-Olkin Measure of Sampling Adequacy & $\mathbf{0 . 9 4 2}$ \\
\hline \multirow{3}{*}{ Bartlett's Test of Sphericity } & Approx. Chi-Square & 14758.3 \\
\cline { 2 - 3 } & Df & 703 \\
\cline { 2 - 3 } & Sig. & 0 \\
\hline
\end{tabular}

\section{Findings}

The results of the factor analysis are as follows: Eight factors were extracted which could explain 63 percent of the variability (refer Table 8). Based on characteristics explained and the extracted factors were renamed as follows: The first extracted factor as "system characteristics, the second extracted factor as perceived risk, the third factor was renamed as perceived trust, the fourth factors was renamed as perceived usefulness, the fifth factor was renamed as self-efficacy, sixth factor was renamed as perceived security, seventh factor was renamed to subjective norms and the eight factor was renamed as lack of human intervention" (refer Table 7). These eight factors together could explain 63 percent of the variability.

Stepwise regression was performed with these eight extracted factors as independent variables with respect to the dependent variable, "How likely customers are to continue using these technologies based banking services in future". Stepwise regression was chosen to identify only the significant factors which could determine continued use of technology based banking services. The results of stepwise regression showed that system characteristics, perceived risk, perceived usefulness, and perceived trust were significant factors influencing continued usage of technology based banking services (refer to Tables 4 \& 5). Self-efficacy, perceived security, subjective norms and lack of human intervention were insignificant in determining continued usage behaviour of technology based banking services (refer to Tables 4 \& 5).

R-Square obtained from stepwise regression is .240, which indicated that the independent variables namely system characteristics, perceived risk, perceived usefulness, and perceived trust could explain 24 percent of the variability of the dependent variable, continued usage behavior of technology based banking services.

In order to determine whether there is significant difference between demographic variables and continued usage behaviour of technology based banking services ANOVA with post hoc test was performed. 
Table 4 Model Summary ${ }^{e}$

\begin{tabular}{|l|c|c|c|c|c|c|c|c|c|c|}
\hline Model & $\mathbf{R}$ & $\begin{array}{c}\mathbf{R} \\
\text { Square }\end{array}$ & $\begin{array}{c}\text { Adjusted } \\
\text { R Square }\end{array}$ & $\begin{array}{c}\text { Error } \\
\text { the } \\
\text { Estimate }\end{array}$ & $\begin{array}{c}\text { R Square } \\
\text { Change }\end{array}$ & $\begin{array}{c}\text { F } \\
\text { Change }\end{array}$ & df1 1 & df2 & $\begin{array}{c}\text { Sig. F } \\
\text { Change }\end{array}$ & $\begin{array}{l}\text { Durbin- } \\
\text { Watson }\end{array}$ \\
\hline $\mathbf{4}$ & $.490^{\mathrm{d}}$ & 0.24 & 0.236 & 0.592 & 0.044 & 44.917 & 1 & 780 & 0 & 1.684 \\
\hline $\begin{array}{l}\text { d. Predictors: (Constant), system_characterstics, perceived_risk, perceived_usefullnes, } \\
\text { perceived_trust }\end{array}$ \\
e. Dependent Variable: How likely are you to continue using these services in future \\
\hline
\end{tabular}

Table 5 Coefficients $^{a}$

\begin{tabular}{|c|c|c|c|c|c|c|}
\hline \multirow{2}{*}{\multicolumn{2}{|c|}{ Model }} & \multicolumn{2}{|c|}{ Unstandardized Coefficients } & \multirow{2}{*}{\begin{tabular}{|c} 
Standardized Coefficients \\
Beta \\
\end{tabular}} & \multirow[t]{2}{*}{$\mathbf{T}$} & \multirow[t]{2}{*}{ Sig. } \\
\hline & & $\mathrm{B}$ & Std. Error & & & \\
\hline \multirow{5}{*}{4} & (Constant) & 1.929 & .021 & & 91.262 & 0.000 \\
\hline & system_characterstics & -.185 & .021 & -.274 & -8.765 & .000 \\
\hline & perceived_risk & .181 & .021 & .267 & 8.558 & .000 \\
\hline & perceived_usefullnes & -.152 & .021 & -.225 & -7.202 & .000 \\
\hline & perceived_trust & -.142 & .021 & -.209 & -6.702 & .000 \\
\hline
\end{tabular}

Table 6 Descriptive and ANOVA Results

\begin{tabular}{|c|c|c|c|c|c|}
\hline \multicolumn{6}{|c|}{ Age } \\
\hline & $\mathrm{N}$ & Mean & Std. Deviation & F Value & Significance \\
\hline Less than or equal to 30 & 169 & 1.70 & .623 & \multirow{5}{*}{19.357} & \multirow{5}{*}{0.00} \\
\hline $31-40$ & 249 & 1.84 & .652 & & \\
\hline $41-50$ & 249 & 2.02 & .695 & & \\
\hline 50 Above & 118 & 2.25 & .616 & & \\
\hline Total & 785 & 1.93 & .678 & & \\
\hline \multicolumn{6}{|c|}{ Level of Education } \\
\hline & $\mathrm{N}$ & Mean & Std. Deviation & F Value & Significance \\
\hline Primary & 69 & 2.52 & .532 & \multirow{8}{*}{39.773} & \multirow{8}{*}{0.00} \\
\hline High School & 93 & 2.42 & 697 & & \\
\hline Secondary & 140 & 2.14 & .552 & & \\
\hline Graduate & 301 & 1.76 & .608 & & \\
\hline Post Graduate & 101 & 1.56 & .555 & & \\
\hline Professiona Degree (BE/M.B.B.S/C.A/C.S) & 77 & 1.57 & .594 & & \\
\hline $\mathrm{PhD}$ & 4 & 1.75 & .500 & & \\
\hline Total & 785 & 1.93 & .678 & & \\
\hline \multicolumn{6}{|c|}{ Occupation } \\
\hline & $\mathrm{N}$ & Mean & Std. Deviation & F Value & Significance \\
\hline Student & 102 & 1.65 & .726 & \multirow{5}{*}{39.529} & \multirow{5}{*}{0.00} \\
\hline Service & 205 & 1.67 & .646 & & \\
\hline Self Employed/Professional & 281 & 1.96 & .572 & & \\
\hline Unemployed & 197 & 2.29 & 649 & & \\
\hline Total & 785 & 1.93 & 678 & & \\
\hline \multicolumn{6}{|c|}{ Income } \\
\hline & $\mathrm{N}$ & Mean & Std. Deviation & F Value & Significance \\
\hline less than 20,000 & 427 & 2.01 & .687 & 5.466 & 0.00 \\
\hline
\end{tabular}




\begin{tabular}{|c|c|c|c|c|c|}
\hline $21000-40000$ & 254 & 1.91 & .650 & & \\
\hline $41000-60000$ & 59 & 1.73 & .715 & & \\
\hline $61000-80000$ & 18 & 1.72 & .461 & & \\
\hline $81000-100000$ & 17 & 1.47 & .514 & & \\
\hline Above 1 lakhs & 10 & 1.40 & .516 & & \\
\hline Total & 785 & 1.93 & .678 & & \\
\hline \multicolumn{6}{|c|}{ Gender } \\
\hline & $\mathrm{N}$ & Mean & Std. Deviation & F Value & Significance \\
\hline Male & 401 & 1.83 & .654 & \multirow{3}{*}{18.519} & \multirow{3}{*}{0.00} \\
\hline Female & 384 & 2.03 & .687 & & \\
\hline Total & 785 & 1.93 & .678 & & \\
\hline
\end{tabular}

The results show that there is a significant difference in continuing usage of technological based banking services with respect to different age groups. Significant difference in terms of intention to continue usage was observed between age group of less than or equal to 30 and age group belonging to (41-50) years, less than or equal to 30 and above 50 years, (31-40) years and (41-50) years, (31-40) years and above 50 years. Bank customers belonging to above 50 years showed greater intention to continue technology based banking service usage than other age group with the highest mean score of 2.25 , followed by $41-50$ years with a mean score of 2.02. Level of education of respondents was found to significantly impact continued usage intention. Difference in intention was observed between, primary level degree holders and secondary degree holders, primary degree and graduates, primary degree and postgraduates and primary degree and professional degree holders. Difference was also observed between high school degree holders and secondary degree holders, high school and graduates, high school and post graduates, high school and professional degree holders. There was also difference in secondary and graduates, secondary and postgraduates, secondary and professional degree, graduate and post graduates. Respondents with primary degree showed high intention for continued usage of technology based banking services with a mean score of 2.52 , followed by respondents with high school degree holders with a mean of 2.42. Occupation of respondents was also found to significantly differ in terms of continued usage intention. Difference among students and self employed/professionals, students and unemployed, service holders and self employed/professionals, service and unemployed respondents groups were observed in terms of intention to continue using technology based banking services. Unemployed respondents group showed highest intention to continue using technology based banking services with a mean score of 2.29, followed by self employed/professionals with a second highest mean of 1.96. Significant difference was also observed in terms of continued usage behaviour of technology based banking services usage with respect to gender. Female respondents showed higher intention to continue technology based banking services usage than male respondents with a mean of 2.03 and 1.83 respectively. There was also significant difference observed in terms of continued usage behaviour of respondents with respect to different income groups. Continued usage intention differed between income group of less than Rs. 20,000 and Rs. (41,000-60,000), less than Rs. 20,000 and Rs. (81,000-100000). Respondents with income level of less than Rs.20, 000 showed higher intention to continue technology based banking 
services usage than respondents with other income groups with a highest mean score of 2.01, followed by income group of Rs. (21000-40,000).

\section{Conclusion}

Continued usage intention of bank customers are influenced partly by system characteristics determinants such as easy paying bills, checking balance instantly, not needing to travel, having easy service access and high speed internet connectivity. Bank customers are also risk averse, and perceive trust as an important factor in influencing continued usage intention. In addition, perceived usefulness determinants such as time saving, quick transaction and easy system use influence continued usage intention. Demographic characteristics like age, level of education, occupation, gender and level of income have significant impact on continued usage intention of bank customers. Bank customers of age 50 years or older showed greater intention to continue using technology based banking services. In terms of level of education, bank customers having primary and high school degree have shown more tendency to continue using technology based banking services than graduate and post graduate degree holders which is just the opposite to results found in adoption intention studies. Bank customer with lower income showed more tendency to continue using technology based banking services and female respondents showed higher intention to continue technology based banking services usage. Therefore, most bank customers with greater intention to continue using technology based banking services comprised of females, lower income groups of less than Rs. 20,000 per month, are older in age (50 years or above ) and having either primary or high school level of education.

\section{Discussion}

Only few studies have been found through literature synthesis of continued usage factors of technology based banking services. These include Kasheir et al, (2009) where, only perceived ease of use was found to be a significant factor in predicting continued usage factor of internet banking among Egyptian bank customers. Kasheir et al, (2009) found demographic variables such as age, income; gender and level of education to be insignificant in predicting continued usage behaviour of technology based banking services which contrast with the present study. A similar study by Gupta and Gupta (2013) from Indian context identified value, technology and channel dimensions as antecedents of continued and frequent usage of internet banking services. However, social dimensions were found to be insignificant in predicting continued usage of internet banking services. Gupta and Gupta (2013) also found demographic variables such as age, gender, income and occupation to be insignificant in predicting continued usage intention of internet banking services among Indian bank customers. A similar study by Cooksey (2013) from Australian context found social dimensions to be insignificant in predicting continued usage intention of internet banking services, whereas value for money, technology and channel dimension was found to be significant predictor of continued usage intention of technology based banking services among Australian customers which is in line with the findings of this study. However demographic factors were found to be insignificant by Cooksey (2013) which again contradicts with the findings of this study. 


\section{Scope and Limitations}

The current research covers only Assam jurisdiction in India. Therefore, future research in the same domain may include other jurisdictions and compare the results with this present study. This study adds to the existing literature on continued usage factors of technological based banking services. This particular study also provide adequate information to technology service providers so that they can fine tune technology based banking products based on customers intention to continue using such services.

Table 7 Rotated Component Matrix ${ }^{a}$

\begin{tabular}{|c|c|c|c|c|c|c|c|c|}
\hline & \multicolumn{8}{|c|}{ Component } \\
\hline & 1 & 2 & 3 & 4 & 5 & 6 & 7 & 8 \\
\hline Paying bill is easy using these services & .834 & & & & & & & \\
\hline I frequently shop online & .808 & & & & & & & \\
\hline I can do banking activities from home & .735 & & & & & & & \\
\hline I frequently need to check balance instantly & .684 & & & & & & & \\
\hline I have easy internet access & .683 & & & & & & & \\
\hline Recharging for services can be done easily & .670 & & & & & & & \\
\hline I do not have to travel to use these services & .647 & & & & & & & \\
\hline I often need to transfer money & .643 & & & & & & & \\
\hline I can easily access these services & .606 & & & & & & & \\
\hline I am familiar/proficient with English language & .595 & & & & & & & \\
\hline $\begin{array}{l}\text { High speed internet connectivity is available in my } \\
\text { area }\end{array}$ & .554 & & & & & & & \\
\hline I am aware of these services & .527 & & & & & & & \\
\hline $\begin{array}{l}\text { There is high risk of machine (ATM, Computer, POS) } \\
\text { failures }\end{array}$ & & .774 & & & & & & \\
\hline Chance of losing money and double payment exist & & .767 & & & & & & \\
\hline It requires sharing personal/sensitive information & & .622 & & & & & & \\
\hline I have technology Phobia & & .619 & & & & & & \\
\hline I do not feel the need to use them & & .584 & & & & & & \\
\hline No customer support is available & & .561 & & & & & & \\
\hline $\begin{array}{l}\text { Online banking website or mobile app interface is } \\
\text { difficult }\end{array}$ & & .559 & & & & & & \\
\hline I find it difficult to locate the services that I seek & & .526 & & & & & & \\
\hline I trust these services & & & .705 & & & & & \\
\hline It is necessary for me to use these services & & & .697 & & & & & \\
\hline It is reliable to use these services & & & .682 & & & & & \\
\hline I have experience using computer and mobile & & & .553 & & & & & \\
\hline It is useful & & & & .832 & & & & \\
\hline Transaction is done quickly & & & & .787 & & & & \\
\hline It saves time & & & & .674 & & & & \\
\hline I find it easy to use these services & & & & .622 & & & & \\
\hline My bank insist that I use these services & & & & & .823 & & & \\
\hline I am comfortable using these services & & & & & .804 & & & \\
\hline These services are complex to use & & & & & .721 & & & \\
\hline Transaction are accurate and error free & & & & & & .720 & & \\
\hline It is secure & & & & & & .713 & & \\
\hline It increase my status & & & & & & & .833 & \\
\hline
\end{tabular}


Cost of using these service is very high

Lack of human intervention

Extraction Method: Principal Component Analysis.

Rotation Method: Varimax with Kaiser Normalization.

a. Rotation converged in 6 iterations.

Table 8 Total Variance Explained

\begin{tabular}{|c|c|c|c|c|c|c|c|c|c|}
\hline \multirow{2}{*}{ Component } & \multicolumn{3}{|c|}{ Initial Eigenvalues } & \multicolumn{3}{|c|}{$\begin{array}{l}\text { Extraction Sums of } \\
\text { Squared Loadings }\end{array}$} & \multicolumn{3}{|c|}{$\begin{array}{l}\text { Rotation Sums of } \\
\text { Squared Loadings } \\
\end{array}$} \\
\hline & Total & $\begin{array}{c}\% \text { of } \\
\text { Variance }\end{array}$ & $\begin{array}{c}\text { Cumulative } \\
\%\end{array}$ & Total & \begin{tabular}{|c|}
$\%$ of \\
Variance
\end{tabular} & $\begin{array}{c}\text { Cumulative } \\
\%\end{array}$ & Total & \begin{tabular}{|c|}
$\%$ of \\
Variance
\end{tabular} & $\begin{array}{c}\text { Cumulative } \\
\%\end{array}$ \\
\hline 1 & 12.029 & 33.413 & 33.413 & 12.029 & 33.413 & 33.413 & 6.821 & \begin{tabular}{|l|}
18.946 \\
\end{tabular} & 18.946 \\
\hline 2 & 2.300 & 6.388 & 39.801 & 2.300 & 6.388 & 39.801 & 4.135 & 11.486 & 30.433 \\
\hline 3 & 2.058 & 5.718 & 45.519 & 2.058 & 5.718 & 45.519 & 3.312 & 9.200 & 39.632 \\
\hline 4 & 1.782 & 4.949 & 50.468 & 1.782 & 4.949 & 50.468 & 2.594 & 7.206 & 46.838 \\
\hline 5 & 1.333 & 3.702 & 54.170 & 1.333 & 3.702 & 54.170 & 1.915 & 5.318 & 52.156 \\
\hline 6 & 1.142 & 3.172 & 57.341 & 1.142 & 3.172 & 57.341 & 1.568 & 4.355 & 56.511 \\
\hline 7 & 1.060 & 2.943 & 60.284 & \begin{tabular}{|l|}
1.060 \\
\end{tabular} & 2.943 & 60.284 & 1.325 & 3.680 & 60.191 \\
\hline 8 & 1.002 & 2.784 & 63.069 & 1.002 & 2.784 & 63.069 & 1.036 & 2.877 & 63.069 \\
\hline 9 & .900 & 2.499 & 65.567 & & & & & & \\
\hline 10 & .811 & 2.254 & 67.821 & & & & & & \\
\hline 11 & .747 & 2.075 & 69.897 & & & & & & \\
\hline 12 & .700 & 1.945 & 71.842 & & & & & & \\
\hline 13 & .676 & 1.877 & 73.718 & & & & & & \\
\hline 14 & .652 & 1.810 & 75.528 & & & & & & \\
\hline 15 & .626 & 1.738 & 77.266 & & & & & & \\
\hline 16 & .610 & 1.695 & 78.961 & & & & & & \\
\hline 17 & .594 & 1.651 & 80.612 & & & & & & \\
\hline 18 & .553 & 1.537 & 82.149 & & & & & & \\
\hline 19 & .518 & 1.440 & 83.589 & & & & & & \\
\hline 20 & .490 & 1.361 & 84.950 & & & & & & \\
\hline 21 & .485 & 1.348 & 86.298 & & & & & & \\
\hline 22 & .458 & 1.272 & 87.570 & & & & & & \\
\hline 23 & .444 & 1.233 & 88.803 & & & & & & \\
\hline 24 & .418 & 1.162 & 89.964 & & & & & & \\
\hline 25 & .400 & 1.112 & 91.076 & & & & & & \\
\hline 26 & .385 & 1.069 & 92.145 & & & & & & \\
\hline 27 & .364 & 1.012 & 93.158 & & & & & & \\
\hline 28 & .338 & .940 & 94.098 & & & & & & \\
\hline 29 & .328 & .912 & 95.009 & & & & & & \\
\hline 30 & .324 & .899 & 95.909 & & & & & & \\
\hline 31 & .313 & .869 & 96.777 & & & & & & \\
\hline 32 & .282 & .783 & 97.560 & & & & & & \\
\hline 33 & .257 & .714 & 98.274 & & & & & & \\
\hline 34 & .241 & .668 & 98.942 & & & & & & \\
\hline 35 & .218 & .606 & 99.549 & & & & & & \\
\hline 36 & .162 & .451 & 100.000 & & & & & & \\
\hline
\end{tabular}


Table 9 Model Summary ${ }^{e}$

\begin{tabular}{|c|c|c|c|c|c|c|c|c|c|c|}
\hline \multirow{2}{*}{ Model } & \multirow{2}{*}{$\mathbf{R}$} & \multirow{2}{*}{$\begin{array}{c}\text { R } \\
\text { Square }\end{array}$} & \multirow{2}{*}{$\begin{array}{l}\text { Adjusted } \\
\text { R Square }\end{array}$} & \multirow{2}{*}{$\begin{array}{l}\text { Std. Error } \\
\text { of the } \\
\text { Estimate }\end{array}$} & \multicolumn{5}{|c|}{ Change Statistics } & \multirow{2}{*}{$\begin{array}{l}\text { Durbin- } \\
\text { Watson }\end{array}$} \\
\hline & & & & & $\begin{array}{c}\mathbf{R} \\
\text { Square }\end{array}$ & $\begin{array}{c}\mathbf{F} \\
\text { Change }\end{array}$ & df1 & df2 & $\begin{array}{c}\text { Sig. F } \\
\text { Change }\end{array}$ & \\
\hline 1 & $.274^{\mathrm{a}}$ & .075 & .074 & .652 & .075 & 63.319 & 1 & 783 & .000 & \\
\hline 2 & $.382^{\mathrm{b}}$ & .146 & .144 & .627 & .071 & 65.320 & 1 & 782 & .000 & \\
\hline 3 & $.443^{\mathrm{c}}$ & .197 & .194 & .609 & .051 & 49.108 & 1 & 781 & .000 & \\
\hline 4 & $490^{\mathrm{d}}$ & .240 & .236 & .592 & .044 & 44.917 & 1 & 780 & .000 & 1.684 \\
\hline \multicolumn{11}{|c|}{ a. Predictors: (Constant), system_characterstics } \\
\hline \multicolumn{11}{|c|}{ b. Predictors: (Constant), system_characterstics, perceived_risk } \\
\hline \multicolumn{11}{|c|}{ c. Predictors: (Constant), system_characterstics, perceived_risk, perceived_usefullnes } \\
\hline \multicolumn{11}{|c|}{ d. Predictors: (Constant), system_characterstics, perceived_risk, perceived_usefullnes, perceived_trust } \\
\hline \multicolumn{11}{|c|}{ e. Dependent Variable: How likely are you to continue using these services in future } \\
\hline
\end{tabular}

Table 10 ANOVA $^{a}$

\begin{tabular}{|c|c|c|c|c|c|c|}
\hline \multicolumn{2}{|r|}{ Model } & Sum of Squares & Df & Mean Square & $\mathbf{F}$ & Sig. \\
\hline \multirow{3}{*}{1} & Regression & 26.934 & 1 & 26.934 & 63.319 & $.000^{\mathrm{b}}$ \\
\hline & Residual & 333.071 & 783 & .425 & & \\
\hline & Total & 360.005 & 784 & & & \\
\hline \multirow{3}{*}{2} & Regression & 52.611 & 2 & 26.305 & 66.920 & $.000^{\mathrm{c}}$ \\
\hline & Residual & 307.394 & 782 & .393 & & \\
\hline & Total & 360.005 & 784 & & & \\
\hline \multirow{3}{*}{3} & Regression & 70.796 & 3 & 23.599 & 63.727 & $.000^{\mathrm{d}}$ \\
\hline & Residual & 289.209 & 781 & .370 & & \\
\hline & Total & 360.005 & 784 & & & \\
\hline \multirow{3}{*}{4} & Regression & 86.543 & 4 & 21.636 & 61.712 & $.000^{\mathrm{e}}$ \\
\hline & Residual & 273.462 & 780 & .351 & & \\
\hline & Total & 360.005 & 784 & & & \\
\hline \multicolumn{7}{|c|}{ a. Dependent Variable: How likely are you to continue using these services in future } \\
\hline \multicolumn{7}{|c|}{ b. Predictors: (Constant), system_characterstics } \\
\hline \multicolumn{7}{|c|}{ c. Predictors: (Constant), system_characterstics, perceived_risk } \\
\hline \multicolumn{7}{|c|}{ d. Predictors: (Constant), system_characterstics, perceived_risk, perceived_usefullnes } \\
\hline \multicolumn{7}{|c|}{ e. Predictors: (Constant), system_characterstics, perceived_risk, perceived_usefullnes, } \\
\hline
\end{tabular}

Table 11 Coefficients $^{a}$

\begin{tabular}{|c|c|c|c|c|c|c|}
\hline \multirow{2}{*}{\multicolumn{2}{|c|}{ Model }} & \multicolumn{2}{|c|}{$\begin{array}{c}\text { Unstandardized } \\
\text { Coefficients }\end{array}$} & \multirow{2}{*}{$\begin{array}{c}\begin{array}{c}\text { Standardized } \\
\text { Coefficients }\end{array} \\
\text { Beta } \\
\end{array}$} & \multirow[t]{2}{*}{$\mathbf{t}$} & \multirow[t]{2}{*}{ Sig. } \\
\hline & & $\mathrm{B}$ & Std. Error & & & \\
\hline \multirow{2}{*}{1} & (Constant) & 1.929 & .023 & & 82.852 & 0.000 \\
\hline & system_characterstics & -.185 & .023 & -.274 & -7.957 & .000 \\
\hline \multirow{3}{*}{2} & (Constant) & 1.929 & .022 & & 86.188 & 0.000 \\
\hline & \begin{tabular}{|l|} 
system_characterstics \\
\end{tabular} & -.185 & .022 & -.274 & -8.278 & .000 \\
\hline & perceived_risk & .181 & .022 & .267 & 8.082 & .000 \\
\hline \multirow{4}{*}{3} & (Constant) & 1.929 & .022 & & 88.799 & 0.000 \\
\hline & system_characterstics & -.185 & .022 & -.274 & -8.529 & .000 \\
\hline & perceived_risk & .181 & .022 & .267 & 8.327 & .000 \\
\hline & perceived_usefullnes & -.152 & .022 & -.225 & -7.008 & .000 \\
\hline
\end{tabular}




\begin{tabular}{|l|l|c|c|c|c|c|}
\hline (Constant) & 1.929 & .021 & & 91.262 & 0.000 \\
\cline { 2 - 7 } system_characterstics & -.185 & .021 & -.274 & -8.765 & .000 \\
\cline { 2 - 7 } & perceived_risk & .181 & .021 & .267 & 8.558 & .000 \\
\cline { 2 - 6 } perceived_usefullnes & -.152 & .021 & -.225 & -7.202 & .000 \\
\hline perceived_trust & -.142 & .021 & -.209 & -6.702 & .000 \\
\hline
\end{tabular}

a. Dependent Variable: How likely are you to continue using these services in future

\section{References}

1. Capece, G \& Campisi, D.,'A Behavioral Model of E-Banking Usage in Italy', International Journal of Engineering Business Management. 5(16), 2013.

2. http://www.censusindia.gov.in/2011-provresults/paper2/data_files/india/Rural_Urban_2011.pdf [Retrieved 30, Dec, 2018].

3. Chandrasekar, V., 'An Empirical Analysis of Factors and Variables influencing internet banking among Bangalore Customers', International Journal of Research in Computer Application and Management. 2 (10). 2012. 143-149.

4. Davis F., 'Perceived Usefulness, Perceived Ease of Use, and User Acceptance of Information Technology', MIS Quarterly. 13 (3), 1989, 319-340.

5. Dubey, M., \& Deshmukh, P., 'E-Banking: Customer Perception in India', Proceedings of National Conference on Emerging Trends: Innovations and Challenges in IT, 19 -20, April 2013. BVIMSR'S Journal of Management Research.

6. Gupta, R., \& Jain, K., 'Adoption behavior of rural India for mobile telephony: A multi group study', Telecommunications Policy. 2015.

7. Hair, J. F, Black, W. C., Babin, B., J., \& Tatham, R., L., (2006). 'Multivariate Data Analysis', $6^{\text {th }}$ Edition, Prentice-Hall, Englewood Cliffs, NJ

8. http://cashlessindia.gov.in/internet_banking.html [Accessed on 9-May-2018]

9. Lee, E.J. \& Lee, J., 'Consumer adoption of internet banking: need-based and/or skill-based', Marketing Management Journal, 11 (1), 2000, 101-13.

10. Lichtenstein, Sharmanand \& Williamson, Kirsty, 'Understanding Consumer Adoption of Internet Banking: An Interpretive Study in the Australian Banking Context', Journal of Electronic Commerce Research, 7(2), 2006, 50-66.

11. Mathieson K., 'Predicting user intentions: Comparing the technology acceptance model with the theory of planned behavior', Information Systems Research, 2, 1991, 173-191.

12. Maxwell, J. A., 'Understanding and validity in qualitative research', Harvard Educational Review, 62(3), 1992, 279-300

13. Mayer, R. C., Schoorman, F. D. \& Davis, J. H., 'An integrative model of organizational trust', The Academy of Management Review, 20 (3), 1995, 709734.

14. Moore C. Gary \& Benbasat Izak, 'Development of Instrument to measure the perception of Adopting an Information Technology Innovation', Information System Research, 2 (3), 1991, 192-222.

15. Morris M., \& Venkatesh, 'Age differences in technology adoption decision: Implications for changing workforce', Personnel Psychology. 53, 2000, 375403. 
16. Mukhtar, Mashood, 'Perception of UK based customers towards Interner Banking in the United Kingdom', Journal of Internet Banking and Commerce, 20 (1), (2015), 1-38.

17. Muzividzi et al., 'An Analysis of factors that influence internet banking adoption among intellectual: Case of Chinhoyi University of technology. Interdisciplinary Journal of Contemporary Research in Business, 4(11), (2013), 350-369.

18. Nielsen, J.F., 'Internet technology and customer linking in Nordic banking', International Journal of Service Industry Management, 13 (5), 2002, 475-95.

19. Ong, C., \& Lai, J., Gender differences in perceptions and relationships among dominants of e-learning acceptance', Computers in Human Behavior, 22(5), 2006, 816-829.

20. Ozdemir, S., \& Trott, P., 'Exploring the adoption of a service innovation: A study of Internet banking adopters and non-adopters', Journal of Financial Services Marketing, 13(4), 2009, 284-299.

21. Singh, S., 'Customer Perception of Mobile Banking: An Empirical Study in National Capital Region Delhi', Journal of Internet Banking and Commerce. 19 (3), 2014, 1-22.

22. Wilcox, R. R., 'Some practical reasons for reconsidering the KolmorogovSmirnov test', British Journal of Mathematical and Statistical Psychology. 50(1), 1997, 9-20

23. Wu, M., \& Kuo, F., "An Empirical Investigation of Habitual Usage and Past Usage on Technology Acceptance Evaluations and Continuance Intention', Database for Advances in Information Systems, 39 (4), 2008, 48-73.

24. Yoon, Shik Hyun \& Occena, L., 'Impact of Customers' perception on Internet Banking Use with Smartphone', Journal of Computer Information Systems, 2014, 1-9

25. Lewis, B. R., 'Service quality: an international comparison of bank customers expectations and perceptions', Journal of Marketing Management, 7 (1), (1991),47-62

\section{About Our Authors}

Chandana Goswami is a professor at Department of Business Administration, Tezpur Central University and is currently serving as the Dean, School of Management Sciences, Tezpur Central University, Assam, India. Her areas of interest includes: General Management, Financial Management and Business Communication.

Kamaleswar Boro is a Research Scholar at Department of Business Administration, Tezpur Central Unioversity, Assam and is currently pursuing his PhD in Banking. 